\title{
A Micro-level Analysis of the Effect of Remittances on Health Expenditures: Evidence from Albania
}

\author{
Ermira H. Kalaj, PhD \\ Aleksander Moisiu University, Durrës
}

\section{Doi:10.5901/mjss.2015.v6n1s1p665}

\begin{abstract}
Using household survey data for Albania, the paper investigates the effect of remittances on health capital accumulation. Total expenditure is divided into two categories: expenditure on medicines and expenditure on visits and laboratory services. The estimation is presented for two separate sub groups, rural and urban area. In the paper both instrumental variable and propensity score matching are used to give answer to the research question about the impact of remittances in the health capital investment. The findings indicate that households increase their expenditure for medicines and other health services in the presence of remittance income. The positive relationship is statistically significant in the case of remittance receiving households living in the rural area. The magnitude is lower in the case of total expenditure for visits and laboratory. However, total expenditure for visits and laboratory are likely to have significant impact on the health outcome given their prevention nature. These findings show that remittance flows pay a heterogeneous role in the decision making process of remittancereceiving household members. However, these non-labor income flows may play an important role in supporting expenditures, especially for those living in rural areas.
\end{abstract}

Keywords: remittances, health expenditure, instrumental variable

\section{Introduction}

As labour markets become internationalized and people increasingly migrate to find work, remittances have become important for the survival of the low-income households in regions of outmigration. Remittance flows, funds received from migrants working abroad, have become enormously important as a source of income in many developing countries (Giuliano and Ruiz-Arranz, 2005; Mundaca, 2009).

There is an ongoing debate on the role of migration in the development of countries with high rates of migration such as Albania. The literature focuses on how remittances are spent by remittance-receiving households and their implications in terms of costs and benefits for the local economy. Researchers disagree over the extent to which remittances-receiving households use these financial resources productively. Some findings suggest the use of remittances mainly for short-term consumption needs rather than for long-term investments. The extent to which remittances contribute to local development depends upon the household context, circumstances and the way decisions are made.

Since the beginning of the transition from a centralized to a market economy Albania has been characterized by rapid growth in the volume of migration with a particular peak in 1997-19981 following the Pyramid Scheme collapse (Azzarri \& Carletto, 2009), and in 2000. Figure 1 shows the flow of the first-time migrant in the period 1991-2004, with a peak in 2000. In conjunction with the migration, the volume of remittances directed to households in Albania has grown rapidly. Remittances represent the most direct and immediate benefit for the remittance-receiving households and the local community. The lack of microeconomic restructuring, however, seems not to have stimulated local production and remittances have generally been used for the consumption of goods (Castaldo \& Reilly, 2007), thus deepening the extroversion of the economy². While remittances are generally flows of small individual transactions and the method of transfers may sometimes be informal or irregular, the total amount of remittances is substantial.

\footnotetext{
1 Peaking in 2000 at about 50.000 new migrants per year and steadily decreasing after that.

${ }^{2}$ Extroversion of the economy: meaning that the local consumption is higher that the GDP, while the difference is compensated by remittances and foreign aid (Samson, 1996).
} 
Figure 1: Flows of first-time migrants by year of migration, 1991-2004

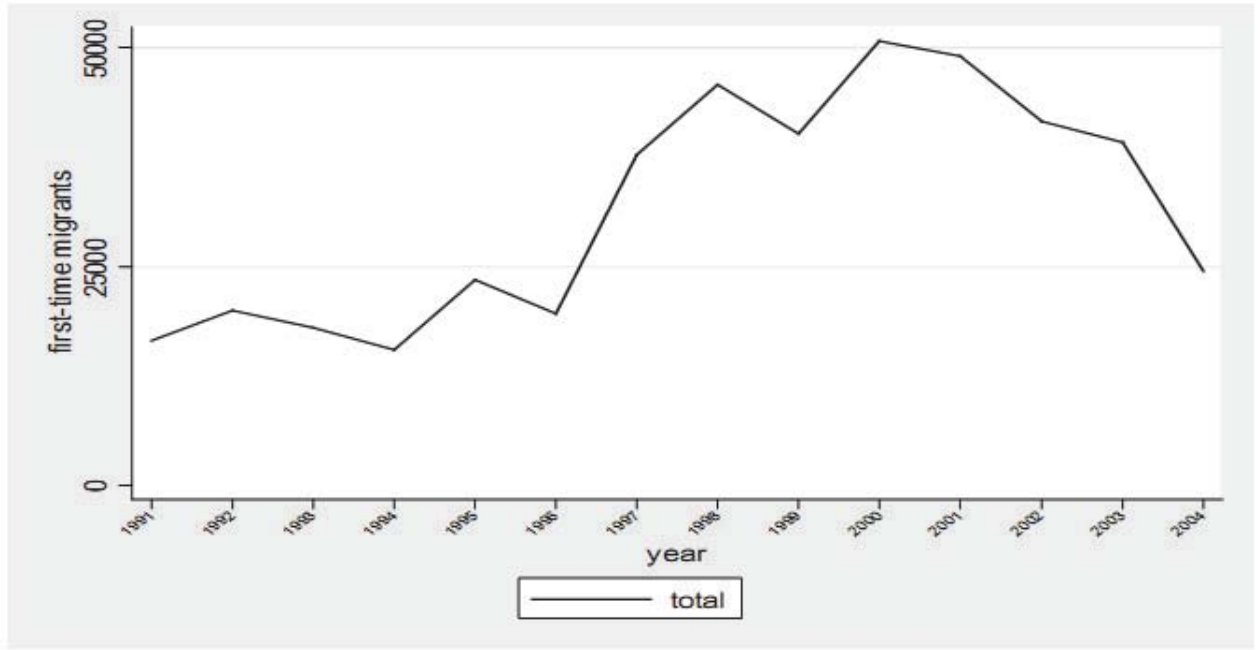

Source: C. Azarri and G. Carletto (2009)

There have been few empirical studies of the impact of remittances on the labor market issues in Albania. Utilizing the Albanian Living Standards Measurement Survey (LSMS) for 1996, Konica and Filer ( 2009) suggest that remittances have a negative effect on female labor market participation due to higher incomes from household members working abroad (Rodriguez \& Tiongson, 2001; Amuendo-Dorantes \& Pozo, 2006). This finding is consistent with studies conducted in other countries. In the Albanian case, however, Konica and Filer (2009) find that neither the existence of emigrants in the household nor the amount of remittances received has an effect on male labor force participation.

Remittances are not only invested in physical capital, but also productively invested in human capital accumulation, such as education. The Becker (1991) model of investment in education states that families take into consideration their education rate of return and its cost in order to choose the optimal education level for their children; in this model a range of factors may influence the educational attainment. If families have financial constraints the level of schooling for their children will be lower than optimal. By relaxing the household's liquidity constraints, remittances from abroad may facilitate investments in education.

Studies of households on Albania have focused mainly on the decision to work and do not consider how remittances impact human capital investment. My second chapter examines how remittances influence decisions to invest in schooling of the household members. Little is so far known about the extent that remittances effect socioeconomic outcomes such as school attainment. According to the literature on remittances, labor migration seems to have contradictory impact on the education of the household members left behind.

The development potential of remittances is increasingly being recognized by researchers and policymakers. This paper examines the contribution of migration and remittances on human capital investment using cross-sectional data for Albania. Health is an important factor of future productivity, in this way it has a direct impact on economic growth and poverty reduction. According to Grossman (1972) health capital differs from other forms of human capital because an individual's stock of knowledge affects her market and nonmarket activities, while "the stock of health" determines the amount of time she can spend earning money and consuming commodities. This brings differences in the demand for health if compared to the demand for other capitals. Health is demanded for two reasons; as a consumption commodity and as an investment commodity. Consumers demand for health is positively correlated with labor incomes. Does this positive relation still hold with non-labor incomes, such as remittances? Do remittances affect household consumption of health? 


\section{The Link between Migration, Remittances and Health Care Expenditure}

In a narrower way other sources of income transfers such as remittances are expected to have positive impact on the health expenditure. In analyzing the role of remittances in the provision of health care it is important to consider the relationship between migration and health.

Using 2002 Mexico Survey, Amuendo-Dorantes and Pozo (2009) find that international remittances raise health expenditures. Approximately 6 pesos of every 100 peso increment in remittance income are spent on health. Health care expenditure is less responsive to remittance income among lower-income households. They also find that households lacking any health care coverage exhibit greater remittance income sensitivity. Hence remittances may contribute to equalization in the usage of health care services by households with and without some kind of health care coverage.

Lindstrom and Munoz-Franco (2006) used data from Guatemala to examine how migration experience and social ties to migrants influence the probability of using maternal health care servoces. They find that remittances are a potential way through which migration affect health care services in rural areas. Migration experience is strongly associated formal delivery assistance. However, this relationship is due to the positive association between migration and enabling resources.

According to Jorge (2008) there is a statistically significant positive relationship between remittances and the household's expenditure on health for households without access to employment's medical insurance. The researcher uses a Tobit model with random effects finding that 10 percent changes in remittances are devoted to health expenditure. The study shows an important difference in the effect between remittances and "institutional transfers".

Using LSMS for 2005 Tomini and Maarse (2011) explores the demand side of informal payments for health care in Albania. They used multivariate logit and OLS to explain informal payments. Their findings suggest differences in determinants of informal payments in inpatients and outpatients care. Informal payments depend on demographic characteristics but are less dependent on income, suggesting homogeneity of payments across income categories.

Given current and projected declines in remittance flows, it is important to understand the role of these transfers in the household's well-being through better health outcomes. This is why the following study will focus on the effect of remittances on the health capital accumulation in Albania. The relationship will be analyzed in two directions; direct and indirect consequences. First, do remittances further more spending on health care and services and second, is there any relationship between migration and remittances with health outcomes or health status.

\section{The Estimation Framework}

The central concern of this study is to understand how remittances influence household health expenditures. Remittances as non-labor income relax budget constraint and may contribute to increase the household medical use. Health care expenditure is modeled as follows (Amuendo-Dorantes et. al. 2009);

$$
H C E=\alpha_{0}+\alpha_{1} R+\alpha_{2} X_{i}+\varepsilon_{i}
$$

In equation (1) Health Care Expenditure (HCE) is given in relation to remittances (R) and the vector of household characteristics. To overcome the endogeneity problem I used an instrument, which is correlated with household remittance income but not with household health care expenditure. I selected the Instrumental Variable (IV) approach introduces an instrumental variable, $\mathrm{z}$, which has the property that changes in $\mathrm{z}$ are associated with changes in $\mathrm{x}$ but do not lead to changes in y (health status and health care expenditure), except indirectly via $\mathrm{x}$. The IV estimator provides a consistent estimator under the very strong assumption that valid instruments exist, where the instruments are variables that satisfy $E(u \mid z)=0$.

To further investigate the dynamic of health expenditure in the suspected presence of endogeneity I will also use the propensity score matching method explained in the previous chapter. The main between the two methods is that propensity scoring uses observable measures to conduct a weight based on selection where IV method rely an instrument variable made for unmeasured factors or characteristics. Both methods present strengths and weaknesses.

In the absence of randomization, observed treatment ${ }^{3}$ is generally not independent outcomes ${ }^{4}$ and moreover the treatment assignment mechanism is not completely observed. In the absence of randomization, propensity score and IV method can lead to unbiased estimates of casual effects under differing assumptions regarding the assignment of the treatment.

\footnotetext{
${ }^{3}$ Remittance receiving status

${ }^{4}$ Higher health expenditure or better health conditions.
} 
The propensity score, which involves comparing households with similar propensity to receive remittances, attempts to balance observed characteristics in the remittance-receiving group as could occur in a randomized experiment. The propensity score for individual $i, e\left(x_{i}\right)=P\left(D_{i}=1 \mid X_{i}=x\right)$, is defined to be the probability to receive remittances given a vector of observed characteristics. Rosenbaum and Rubin (1983) have shown that matching on the propensity score produces treatment groups that are balanced. Thaus, under the assumption that the treatment assignment is ignorable, unbiased estimates of the average causal effect can be obtained by comparing individuals with similar values of the propensity score.

\section{Results}

Recognizing the endogeneity of migration and remittances I am using Instrumental Variable techniques. I find an instrumental variable that is correlated with remittances but not correlated with health care behavior of household members. Amuendo-Dorantes, et al., (2007) instrument remittances usign information on the percent of migrants in the state of residency and information on the per capita count of the Western Union offices in the country during the previous year.

The instruments used by Kilic, et al., (2007) include whether a household member spoke either Greek or Italian, whether the head of the household had any family relative or friend living abroad in 1990, the diastance in kilometers between the place of residence and the closest point exit from Albania, the annual average number of economic and labor market shocks experienced by the households, and whether the household owned a satellite dish in 1990. All these variables may satisfy the criteria for a valid instrument; they may influence the amount of remittances or the decision to migrate and may not have a direct connection with health care attitudes. In my study I will use a set of three instrumental variables; the number of household members living abroad, the country where the migrants are currently living, and whether a household member spoke Greek or Italian.

Greece and Italy are the major destinations for the Albanian migrants and knowledge on the language of the country of destination may reduce the cost of migration and the possibility of migrants to send remittances back home. The flow of remittances may be determined by the number of household members living abroad and the country of residence of the migrants. These instruments are not correlated to the health care behavior and health care expenditure of household members left behind.

Table 1 reports on the impact of remittances on the total expenditure for medicines. The IV estimates for the overall sample indicate that, receiving remittances has a greater impact in terms of magnitude to the total expenditure for medicines. However in both cases remittance incomes do not seem to be statistically significant. Results are represented in the table divided into two sub groups rural and urban. The IV estimates show that remittance incomes have a positive and statistically significant effect only in the case of rural remittance receiving households meaning that the total expenditure for medicines rise with the presence of remittances in the rural area.

For the entire sample the non-IV estimates show that the total expenditure rises if the household member is older, female, the head of the household and living in the mountain area of the country. In the other hand total expenditure for medicine lower if the household member has more years of education, has a health license, is not working and the household size is greater. The direction of the relationship still holds in the IV-estimates for the entire sample, except for the case of having a health license. In the presence of remittances, expenditure for medicines increases depending on the results presented by the IV-estimates. We notice an increase in the magnitude of total expenditure for medicines in the case of female household members.

In the rural sub group the IV-estimates show a positive and statistically significant impact of remittances. In the same sub group positive impact in the total expenditure for medicines have age, the possession of a health license, being the head of the household and not working.

Surprisingly the relationship between total expenditure in medicines and the income net from remittances is negative in the case of households living in the rural area. These results are not in line with the literature related with the health care behavior. More educated household members spent less for medicines; however we notice that the magnitude is lower in the rural sub group if compared to the urban sub group. In this case we can conclude that more educated household members focus more on prevention. Interesting in this sub group is the positive relation in the case of households living in the mountain area. The difficulties of the access to medical service infrastructures maybe one of the reasons of this relationship.

In the urban sub group the non-IV estimates show that total expenditures for medicines increase with age, female status, being the household head and living in the mountain area. In the other side the total expenditure for medicines 
lower in the presence of a health license, if the household size is greater, if the household member is not working and if more educated. In the urban sub group the magnitude for educated household members is higher if compared to the rural sub group. This result is higher in the case of urban sub group IV-estimates.

Table 1: The Impact of Remittances on the Total Expenditure for Medicines

\begin{tabular}{|c|c|c|c|c|c|c|}
\hline \multirow{2}{*}{ Total Expenditure for Medicines } & \multicolumn{2}{|c|}{ All } & \multicolumn{2}{|c|}{ Rural } & \multicolumn{2}{|c|}{ Urban } \\
\hline & NolV & IV & NoIV & IV & NolV & IV \\
\hline Receive Remittances & $\begin{array}{c}384.060 \\
(799.926)\end{array}$ & $\begin{array}{c}1168.343 \\
(10376.090)\end{array}$ & $\begin{array}{c}154.750 \\
(447.714)\end{array}$ & $\begin{array}{c}9388.832 \\
(4083.426)^{\star \star}\end{array}$ & $\begin{array}{c}272.937 \\
(1700.557)\end{array}$ & $\begin{array}{c}34154.830 \\
(58174.190)\end{array}$ \\
\hline Urban & $\begin{array}{c}2793.112 \\
(932.073)^{\star \star}\end{array}$ & $\begin{array}{c}2352.49 \\
(978.453)^{\star \star}\end{array}$ & - & - & & \\
\hline Education & $\begin{array}{c}-369.817 \\
(116.674)^{\star *}\end{array}$ & $\begin{array}{c}-300.846 \\
(127.344)^{\star *}\end{array}$ & $\begin{array}{l}-86.950 \\
(71.338)\end{array}$ & $\begin{array}{l}-31.824 \\
(84.476)\end{array}$ & $\begin{array}{c}-683.623 \\
(231.441)^{\star \star}\end{array}$ & $\begin{array}{c}-838.034 \\
(478.271)^{\star}\end{array}$ \\
\hline Age & $\begin{array}{c}27.673 \\
(78.495)\end{array}$ & $\begin{array}{c}4.833 \\
(82.974)\end{array}$ & $\begin{array}{c}43.407 \\
(41.669)\end{array}$ & $\begin{array}{c}35.549 \\
(49.049)\end{array}$ & $\begin{array}{c}35.463 \\
(178.717)\end{array}$ & $\begin{array}{c}111.065 \\
(319.190)\end{array}$ \\
\hline Age Squared & $\begin{array}{l}.713 \\
(.983)\end{array}$ & $\begin{array}{c}.840 \\
(1.042)\end{array}$ & $\begin{array}{l}.488 \\
(.518)\end{array}$ & $\begin{array}{l}.595 \\
(.603)\end{array}$ & $\begin{array}{c}1.939 \\
(2.268)\end{array}$ & $\begin{array}{c}-.574 \\
(4.138)\end{array}$ \\
\hline Female & $\begin{array}{c}1415.409 \\
(859.931)^{\star}\end{array}$ & $\begin{array}{c}2151.001 \\
(947.255)^{\star \star}\end{array}$ & $\begin{array}{c}1231.827 \\
(483.821)^{\star \star}\end{array}$ & $\begin{array}{c}1652.88 \\
(589.035)^{\star \star \star}\end{array}$ & $\begin{array}{c}1036.402 \\
(1798.877)\end{array}$ & $\begin{array}{c}4229.389 \\
(3070.196)\end{array}$ \\
\hline Has Health License & $\begin{array}{l}-613.849 \\
(840.010)\end{array}$ & $\begin{array}{c}188.129 \\
(875.050)\end{array}$ & $\begin{array}{c}769.928 \\
(520.518)\end{array}$ & $\begin{array}{c}1691.686 \\
(654.832)^{\star \star}\end{array}$ & $\begin{array}{l}-2119.058 \\
(1611.866)\end{array}$ & $\begin{array}{c}1044.025 \\
(3550.328)\end{array}$ \\
\hline Income net Remittances & $\begin{array}{c}.029 \\
(.013)^{*}\end{array}$ & $\begin{array}{l}.016 \\
(.013)\end{array}$ & $\begin{array}{c}-.030 \\
(.010)^{\star \star \star}\end{array}$ & $\begin{array}{c}-.041 \\
(.012)^{\star \star \star}\end{array}$ & $\begin{array}{c}.053 \\
(.022)^{\star \star}\end{array}$ & $\begin{array}{l}.019 \\
(.043)\end{array}$ \\
\hline HH size & $\begin{array}{c}-493.059 \\
(221.284)^{\star *}\end{array}$ & $\begin{array}{l}-243.956 \\
(362.169)\end{array}$ & $\begin{array}{c}35.135 \\
(118.632)\end{array}$ & $\begin{array}{c}509.870 \\
(198.529)^{\star \star}\end{array}$ & $\begin{array}{l}-1181.125 \\
(507.235)^{\star *}\end{array}$ & $\begin{array}{c}-1543.127 \\
(1115.884)\end{array}$ \\
\hline Not working & $\begin{array}{c}-258.674 \\
(773.891)\end{array}$ & $\begin{array}{l}-274.439 \\
(874.495)\end{array}$ & $\begin{array}{c}1116.467 \\
(464.411)^{\star *}\end{array}$ & $\begin{array}{c}1808.881 \\
(600.710)^{\star \star \star}\end{array}$ & $\begin{array}{c}-674.316 \\
(1524.258)\end{array}$ & $\begin{array}{c}-77.491 \\
(1700.451)\end{array}$ \\
\hline Coastal & $\begin{array}{c}1273.667 \\
(1202.893)\end{array}$ & $\begin{array}{c}885.392 \\
(1300.407)\end{array}$ & $\begin{array}{l}-239.888 \\
(496.536)\end{array}$ & $\begin{array}{c}762.802 \\
(618.770)\end{array}$ & $\begin{array}{c}-41.474 \\
(1908.727)\end{array}$ & $\begin{array}{c}2298.664 \\
(4170.608)\end{array}$ \\
\hline Central & $\begin{array}{c}1629.174 \\
(1269.352)\end{array}$ & $\begin{array}{c}1519.742 \\
(1506.061)\end{array}$ & $\begin{array}{c}1234.121 \\
(1165.540)\end{array}$ & $\begin{array}{c}386.602 \\
(633.302)\end{array}$ & $\begin{array}{c}-343.613 \\
(2121.748)\end{array}$ & $\begin{array}{c}751.246 \\
(2549.583)\end{array}$ \\
\hline Mountain & $\begin{array}{c}4378.423 \\
(1301.748)^{\star \star \star}\end{array}$ & $\begin{array}{c}3150.895 \\
(1372.600)^{\star \star}\end{array}$ & $\begin{array}{c}496.536 \\
(526.829)\end{array}$ & $\begin{array}{c}156.980 \\
(27.430)^{\star \star \star}\end{array}$ & $\begin{array}{c}9519.731 \\
(2250.697)^{\star \star \star}\end{array}$ & $\begin{array}{c}6262.789 \\
(2473.883)^{\star *}\end{array}$ \\
\hline Head of $\mathrm{HH}$ & $\begin{array}{c}4516.190 \\
(1214.094)^{\star \star \star}\end{array}$ & $\begin{array}{c}4263.074 \\
(1331.845)^{\star \star \star}\end{array}$ & $\begin{array}{c}1293.200 \\
(692.992)^{\star}\end{array}$ & $\begin{array}{c}1727.736 \\
(835.200)^{\star *}\end{array}$ & $\begin{array}{c}6736.172 \\
(2528.164)^{\star \star \star}\end{array}$ & $\begin{array}{c}6741.399 \\
(3085.784)^{\star \star}\end{array}$ \\
\hline Cons & $\begin{array}{c}1457.852 \\
(2470.532) \\
\end{array}$ & $\begin{array}{c}279.485 \\
(4912.204) \\
\end{array}$ & $\begin{array}{c}1698.405 \\
(1205.592)\end{array}$ & $\begin{array}{c}-4575.805 \\
(2380.743)^{\star \star}\end{array}$ & $\begin{array}{c}9001.387 \\
(5184.701)^{\star}\end{array}$ & $\begin{array}{c}18176.340 \\
(19160.380)\end{array}$ \\
\hline $\mathrm{N}$ & 8,129 & 6,328 & 4,419 & 3,538 & 3,710 & 2,790 \\
\hline R-squared & 0.014 & 0.011 & 0.031 & - & 0.019 & - \\
\hline Wald chi2(14) & - & 76.57 & - & 112.98 & - & 33.58 \\
\hline Prob>chi2 & - & 0.000 & 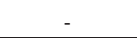 & 0.000 & 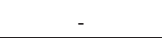 & 0.001 \\
\hline
\end{tabular}

Note: ${ }^{* * *},{ }^{* *}$, and * indicate the statistic significance respectively at 1, 5 and 10 percent level or better.

Table 2 reports variables affecting the total expenditure for medical visits and laboratory services. This dependent variable may be considered as the one describing prevention behavior. The results are presented divided by sub groups of households living in urban and rural area. The main variable of interest for us is remittance income. The IV-estimates suggest that remittances have a positive impact in the expenditure for medical visits and laboratory service. This relationship holds in rural sub group; however the magnitude is higher in the urban sub group but not statistically significant. Remittance income positively affects the expenditure in medical visits and laboratory services in the entire sample.

The OLS estimates show that the total expenditure increases in the urban area. In contrast with the findings in table 1, the relation between total expenditure for visits and the education is positive. More years of education lead to higher expenditure for visits and laboratory services. This result may be related to a higher propensity of educated household members to the prevention through visits and other similar services.

As expected higher age means higher expenditure for visits and laboratory services. Referring to the theory, the human capital formation predicts a positive correlation of the demand for health care and the rate of depreciation on the 
health stock. The OLS estimates show that the magnitude is higher in the urban area if compared to the entire sample and the rural area.

Total expenditure estimates show that the estimated relation is positive for female household members. Male household members are less intensive users of the health care system because they face a higher opportunity cost in compared to female household members. All other things being the same we can expect household size to negatively affect the expenditure for visits and laboratory work. The coefficient is negative in the case of the entire sample and the rural sub group. Larger households will have a lower per capita income reducing the demand for health care. However the IV-estimate is positive in the urban sub group. Being the head of the household means a higher expenditure for visits and laboratory work.

The direction of the relation is negative for all the three areas of residence; Coastal, Central and Mountain. However the effect does not have a clear direction if divided by sub groups. Income net from remittances has a positive effect either in the entire sample or in the sub groups. The theoretical model predicts that the elasticity of demand for all forms of medical services with respect to income should be positive unless it is considered an inferior good. The effect of non-working status ${ }^{5}$ is negative in the sample but have different direction for the sub groups suggesting a positive relation in the rural area and a negative one in the urban area.

\section{Propensity Score Estimation of the Health Expenditure}

Result of the Average Treatment Effect on health expenditure and total amount paid for medicines on the basis of Propensity Score matching are reported in table 2. The Propensity score estimators used in this part of the study are the Kernel and Nearest Neighbor estimators.

In table 2 the average treatment effect (ATE) for an individual drawn from the overall population at random, is 1086.13 lek (for the total amount paid for medicines). This means that the amount spent by a randomly drawn individual would be 1086.13 lek higher because of the participation in the treatment group so receiving remittances. This results because a positive effect is estimated for the untreated (ATU), non remittance-receiving households who are much more numerous than the treated ${ }^{6}$. So the ATE does not have a direct interpretation for the evaluation of the presence of remittances.

Table 2: Estimation of the average treatment effect for health expenditure and medicine expenses

\begin{tabular}{c|ccccccc}
\hline & \multicolumn{3}{c}{ Total Paid for Medicines } & \multicolumn{2}{c}{ Total paid for Health Services } \\
\multicolumn{2}{c}{} & Treated & Controls & Differences & Treated & Controls & Differences \\
\hline Nearest Neighbor Estimator & & & & & & \\
Unmatched & 4164.86 & 4436.47 & -271.61 & 1123.04 \\
& & & $(795.39)$ & 10385.35 & 11508.40 & $(1187.03)$ \\
ATT & 4164.86 & 2689,21 & 1475.65 & 10385.35 & 8800.17 & 1585.18 \\
ATU & 4436.47 & 3502.92 & -933.55 & 11508.40 & 10645.88 & -862.52 \\
ATE & & & -1086.13 & & & -173.58 \\
Kernel Estimator & & & & & & -1123.04 \\
Unmatched & 4164.86 & 4436.47 & $-271.61(795.39)$ & 10385.35 & 11508.40 & $(1187.03)$ \\
& & & & & & -340.50 \\
ATT & 4164.86 & 4029,10 & $135.76(726.03)$ & 10385.35 & 10725.86 & $(1157.71)$ \\
ATU & 4436.47 & 4401.24 & -35.23 & 11508.40 & 12036.40 & 528.00 \\
ATE & & & -63.53 & & & 283.55 \\
\hline
\end{tabular}

The ATU is estimated by matching a similar remittance-receiving individual to a non remittance-receiving individual. Because of the small number of individuals receiving remittances one would have to check if the balancing is also achieved for this group otherwise the ATU might be biased. However, ATE, ATU, and ATT are linked as follows; ATE= $\mathrm{N}_{1}$ $/ N^{*} A T T+N_{0} / N^{*} A T U$, where $N_{1}$ is the number of treated and $N_{0}$ is the number of untreated. So the number of treated and untreated is important in drawing final conclusion.

\footnotetext{
5 The household members maybe unemployed, or out of the labor force, (e.g. children and older members).

${ }^{6}$ From the estimation the support is divided in 2,288 treated and 5,841 untreated.
} 
However, the sign of the ATT (average treatment effect on the treated) is important in giving answer to the question about the presence of remittances. The positive sign of ATT means that the total amount paid for medicines is raised by 1475.65 lek if the individual receive remittances. This positive result is evident when used both kernel and NN estimator. While, we cannot draw the same conclusions for the health service expenditures. Different estimators give different directions of the relationship. These results according to the estimated standard errors are not statistically significant.

Before running psmatch2 in order to obtain the above average treatment effect, a probit regression is analyzed. The findings are similar to those presented after the use of IV method both in the direction of relationship and the magnitude. There are differences in the effect of remittances in the urban areas in the direction of the relation is the opposite of the one presented using IV method, the same difference is noticed for the female variable.

Figure 2: Estimation of propensity score distribution
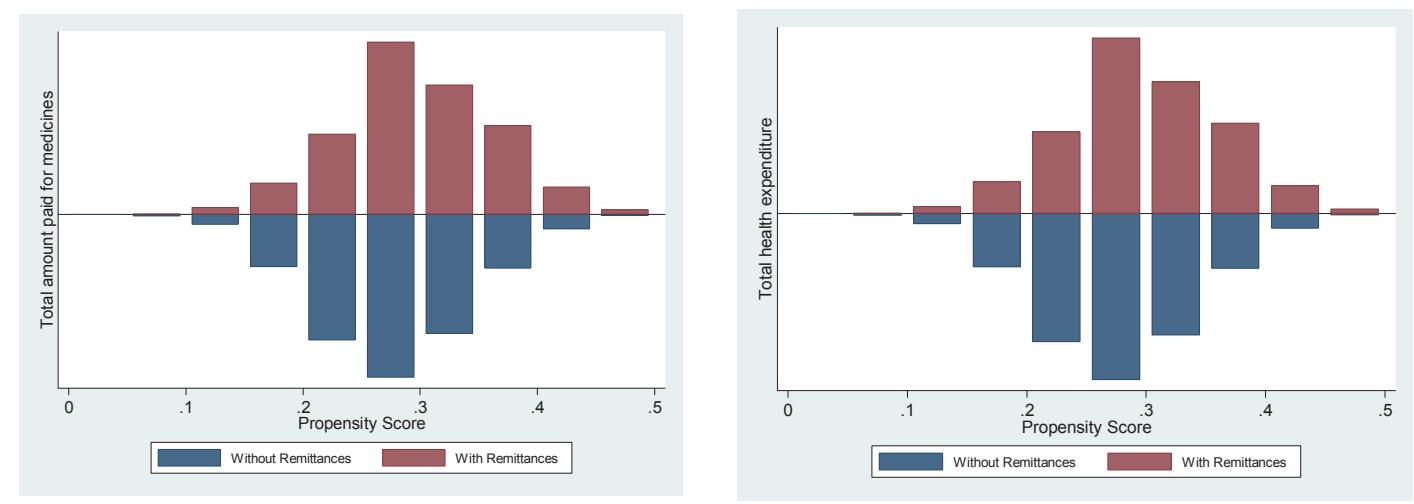

One of the assumptions of the propensity score method is that related to the common support or better the measure of the overlap of the distribution of the propensities. If the assumption holds, there must be an overlap of the propensity scores of remittance-receiving and non remittance receiving households. The results are presented for the total amount paid for medicines and health services in figure 2 .

Figure 2 represents the differences in terms of amounts paid for medicines and health services of the two groups of remittance-receiving and non remittance-receiving conditional to the covariates. The histograms show the distribution of the predicted propensity score between receiving-remittance household members and non receiving-remittance household members. We notice that there is a good overlap between distributions of the propensity score in the two treatment group,.

\section{Concluding Remarks}

The paper examines the relationship between remittance income and total expenditure for health care using instrumental variable method. Total expenditure is divided into two categories: expenditure going in medicines and expenditure going in visits and laboratory services. The estimation is presented for two separate sub group rural and urban area.

The overall findings of the study indicate that households increase their expenditure for medicines and other health services in presence of remittance income. The positive relationship is statistically significant in the case of remittance receiving households living in the rural area. The IV-estimates show that total expenditure for medicines increase by around 9,400 Lek in the case of households living in the rural area of the country. The magnitude is lower in the case of total expenditure for visits and laboratory. However, total expenditure for visits and laboratory are likely to have significant impact on the health outcome given their prevention nature. Remittance flows may play an important policy role in supporting total expenditure for the health care of remittance receiving households, especially for those living in rural area where the access is limited if compared to the urban area.

According to the IV-estimates more years of education means less expenditure for medicines but more for visits and laboratory services. This may be related with the fact that educated household members are more efficient producers of health meaning that they are more skilful in combining medical prevention services for better health outcomes. The 
total health care expenditure increases with age, for female household members, and households living in the mountain area of the country.

Part of the research is the estimation of remittance income in the self-reported health condition. OLS estimates show a positive impact of remittances in increasing the probability of reporting good or very good health condition; however the effect is not statistically significant. Interesting is that the presence of remittance income lowers the probability of chronicle or sudden illness.

Alongside the IV method I used propensity score analysis to estimate the causal effect of remittances in the amount paid for medicines and health services. Propensity score analyses indicate a small but significant benefit of households associated with the receipt of remittances. In the presence of remittances households increase their expenditure for medicines and other health services. This positive effect is more evident in the rural, mountain area. As mentioned previously IV-estimates were also consistent with a higher benefit for remittance-receiving households. However, results obtain from the propensity score estimates are not statistically significant.

Both propensity score and IV approaches rely on critical assumptions and are subjects to biases if the assumptions are not met. On the other side, if there is heterogeneity in the impact of remittances, propensity score and IV estimates of causal effect may differ even if the assumptions are valid. Propensity score analyses rely on the assumption that conditional on observed data, remittances are randomly assigned. In contrast, IV approach relies on the identification of good instruments. The greater the ability of the instrument to predict treatment, the larger the size of the matching population.

The policy implications of the presence of remittances and the effect they have in health expenditure of household members are also important in choosing the right analytic strategy. Observed characteristics of the set of individuals used to compute the propensity score causal estimates allow us to identify characteristics of the reference population and thus make recommendations for individuals. On the other hand, IV approaches may be more applicable because they demonstrate the marginal effects of different changes.

\section{References}

Acosta, P., Lartey, E. \& Mandelman, F., 2009. Remittances and Dutch Disease. Journal of International Economics, 79(1), pp. 102-116. Aggarwal, R., Demirguc-Kunt, A. \& Peria, M., 2006. Do Workers Remittances Promote Financial Development?. In: World Bank Policy Research Paper 3957. Washington DC: The World Bank.

Amuendo-Dorantes, C., Sainz, T. \& Pozo, S., 2007. Remittances and Healthcare Expediture Patterns of Populations in Origin Communities; Evidence from Mexico. Institute for the Integrstion of Latin America and Caribbean.

Azzarri, C. \& Carletto, G., 2009. Modeling Migration Dynamics in Albania, A Hazard Function Approach. In: World Bank Policy Research Paper 4945. Washington DC: The World Bank.

Bank of Albania, 2011. Annual Report, Tirana: The Bank of Albania.

Becker, G., 1991. A Treatise on the Family. (Enlarged Edition) ed. Cambridge: Harvard University Press.

Bloom, D., Canning, D. \& Sevilla, Y., 2004. The Effect of Health on Economic Growth: A production Function Approach. World Development, 32(1), pp. 1-13.

Caliendo, M. \& Kopeinig, S., 2005. Some Practical Guidance for the Implementation of Propensity Score Matching, Berlin: German Institute for Economic Research.

Castaldo, A. \& Reilly, B., 2007. Do Migrant Remittances Affect the Consumption Patterns of Albanian Household?. South-Eastern Europe Journal of Economics, Volume 1, pp. 25-54.

Cleves, M., Gould, W., Gutierrez, R. \& Marchenko, Y., 2008. An Introduction to Survival Analysis Using Stata. Texas: Stata Press.

Frank, R. \& Hummer, R., 2002. The Other Side of the Paradox; The Risk of Low Birth Weight Among Infants of Migrant and Nonmigrant Households within Mexico. International Migration Review, Volume 36, pp. 746-765.

Froelich, M., 2004. Finite Sample Properties of Propensity Score Matching and Weighting Estimators. The Review of Economics and Statistics, Volume 28, pp. 77-90.

Guo, S. \& Fraser, M., 2010. Propensity Score Analysis: Statistical Methods and Applications. s.l.:Sage Publications.

Hildebrandt, N. \& McKenzie, D., 2005. The effect of Migration on Child Health in Mexico. World Bank Policy Working Paper Series 3573. INSTAT, 2012. Main Economic Indicators, Tirana: Institue of Statistics of Albania.

Jorge, N., 2008. Remittances and Household's Expenditures on Health . In: MPRA Papers. Munich: University Library of Munich.

Kanaiaupuni, S. \& Donato, K., 1999. Migradollars and Mortality: The Effects of Migration on the Infant Survival in Mexico. Demography, 36(3), pp. 339-353.

King, R., 2005. Albania as a Laboratory for the Study of Migration and Development. Journal of Southern Europe and Balkans, 7(2), pp. 134-155.

Lindstrom, D. \& Munoz-Franco, E., 2006. Migration and Maternal Health Services Utilization in Rural Guatemala.. Social Scieces and Medicine, Volume 63 (3), pp. 706-721.

Rosenbaum, P., 2005. Sensitivity Analysis in Observational Studies. Encyclopedia of Statistics in Behavioral Studies, pp. 1809-1814. 
Rosenbaum, P. \& Rubin, D., 1983. The Central Role of the Propensity Score in Observational Studies for Casual Effects. Biometrika, Volume 70, pp. 41-55.

Stecklov, G., Carletto, C., Azarri, C. \& Davis, B., 2010. Gender and Migration from Albania. Demography, 47(4), pp. 935-961.

Vidal, R., 1998. The Effect of Emigration on Human Capital Formation. Journal of Population Economics, Volume 11, pp. 589-600.

Wagstaff, A. \& Menno, P., 2005. Health Insurance Impacts on Health and Nonmedical Consumption in a Developing Country. Policy Research Working Paper Series.

WHO, 2012. Albania Health Profile, s.l.: The World Health Organization.

Wooldridge, J., 2002. Econometric Analysis of Cross Section and Panel Data. Massachusetts: MIT Press.

World Bank, 2010. Albania: The New Growth Agenda, A Country Economic Memorandum, Washington DC: The World Bank.

Zweifel, P., Breyer, F. \& Kifmann, M., 2009. Health Economics. Heidelberg: Springer-Verlag. 